\title{
REPORT ON THE PROGRESS OF CONSPECTUS FLORAE ANGOLENSIS
}

The political changes that have taken place in recent years both in Portugal and Angola have, to a certain extent, influenced the development of 'Conspectus Florae Angolensis'. In fact, since the last report on the progress of this work was presented viz. A. Fernandes in Boissiera 24: 617-619 (1976), only a single volume has been published, this being the Pteridophyta by E. A. C. L. E. Schelpe (Selaginellaceae and Isoetaceae by E. A. C. L. E. Schelpe \& A. C. Jermy, and Marsileaceae by E. Launert). This volume runs to 197 pages with 33 line-drawing plates and covers all 26 families of Pteridophyta that have been found in Angola. It was published in Lisbon on August 25th 1977 by the Junta de Investigações Científicas do Ultramar (Overseas Scientific Research Board) which also funded the publication; the Portuguese version of the English manuscript was prepared by Rosette B. Fernandes and E. J. Mendes.

Meantime, it was decided that the creation of an Editorial Board would be desirable, and that all the institutions promoting the project should be represented on this Board, namely the Instituto Botânico da Universidade de Coimbra and the Department of Botany of the British Museum (Natural History), foundation members since the first fascicle of the C.F.A. was published in 1937, the Centro de Botânica da Junta de Investigaçōes do Ultramar which joined them in 1960 , and also more recently, in 1980, the Departamento de Ciências Biológicas, of the Centro Nacional de Investigação Científica, Luanda. Those presently representing these institutions as members of the Editorial Board are Rosette B. Fernandes, E. Launert, E. J. Mendes and $\mathrm{O}$. J. A. de Menezes, respectively.

The next fascicle of this work, dealing with the Crassulaceae, by Rosette B. Fernandes, is scheduled for publication at the end of 1981 or the beginning of 1982 , and will complete the publication of all the families of the Polypetalae that are known to be represented in Angola. The delay in publishing the study on the Crassulaceae is due to the death at a 
very old age of Raymond-Hamet, who had initially been in charge of studying this family.

The present members of the Editorial Board of the C.F.A. are endeavouring to obtain international assistance from various experts, and the following authors have already promised their co-operation for the preparation of the accounts of the following families: Loganiaceae and Apocynaceae (A. J. M. Leeuwenberg, Wageningen), Ericaceae (R. Ross, London), Lobeliaceae (M. Thulin, Uppsala), Ebenaceae (F. White, Oxford); Portuguese taxonomists have been asked to prepare texts for the following families: Bignoniaceae (E. J. Mendes \& Maria
Adélia Diniz; LISC); Boraginaceae (E. S. Martins; LISC); Convolvulaceae (Maria Leonor Gonçalves; LISC); Gentianaceae (J. Paiva; COI); Solanaceae (A. E. Gonçalves; LISC) and Verbenaceae (Rosette B. Fernandes; COI). Thus we believe that significant progress in the publication of the C.F.A. will be achieved in the near future.

E. J. MENDES*

* Centro de Botânica, Junta de Investigaçōes Científicas do Ultramar, Rua da Junqueira 86, P-1300 Lisboa, Portugal. 